\title{
De betekenis van Johan Buitendags stellingname in theologie der natuur
}

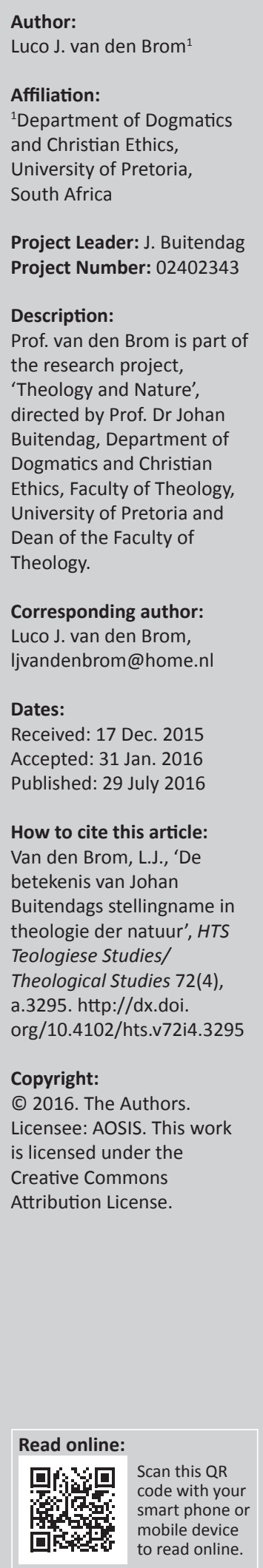

This article presents the importance of Buitendag's stance in the so-called 'theology of nature'. His theological statements endeavour to understand reality in conversation with other academic disciplines to see things in a wider and holistic perspective. Following a suggestion of Moltmann, theology must not restrict itself to internal ecclesiastical and personal faith topics but search for 'the truth of the whole'. It is argued that Buitendag's concept of holism is different from Moltmann's 'the truth of the whole'. Moltmann's holism is eschatologically directed after history, but is meaningless in a contemporary debate. His concept of history seems to be problematic too. Buitendag's holism is more Quinean as a comprehensive relative approach, bottom-up from contemporary insights within different academic disciplines. His theological approach looks like an ellipsis, involving both an ontological and epistemological focus. He defends (Trinitarian) communion as the primary concept, ontologically, which biologists may recognise in their observations of animal communities too. His theology shows a panentheistic perspective for the discourse on divine immanent agency by using as analogy the mind-body relationship in a sophisticated way. Buitendag shows the importance of this perspective for theological hermeneutics. This article presents some logical and theological problems in a panentheistic view which some prominent supporters defend as 'reality depicting'. Buitendag avoids this because of a relational ontology.

\section{Inleiding}

Systematische theologie vormt in de visie van Johan Buitendag een inzet of een streven om de werkelijkheid te verstaan. In een seculariserende cultuur is dat een moedige uitspraak voor een theoloog. Hij geeft daarvoor ook argumenten. Hij spreekt niet over de werkelijkheid zoals deze zich aan ons voordoet (Kants 'Wirklichkeit als Erscheinung'), maar over het geheel der dingen 'soos dit kwansuis is' (Buitendag 2013:1). In Buitendags visie betekent dit dat systematische theologie probeert te begrijpen hoe de werkelijkheid in elkaar steekt wanneer wij daarmee geconfronteerd worden. Bij deze poging om de werkelijkheid te verstaan nodigt hij zijn gesprekspartners uit om voor een goed begrip ook naar stemmen te luisteren die vanuit verschillende wetenschapsgebieden eveneens een poging doen om onze leefwereld te begrijpen. Daarbij denkt Buitendag niet alleen aan de manier waarop allerlei disciplines van de menswetenschappen naar de ons omringende werkelijkheid kijken, maar is hij juist ook geïnteresseerd naar dergelijke uitspraken die vanuit de natuurwetenschappen klinken die een systematisch theoloog te denken geven bij de beeldvorming van de werkelijkheid 'soos die kwansuis is'. Daarbij streeft hij naar een 'theologie van de natuur' die de natuurlijke leefwereld in relatie tot God probeert te verstaan. Deze onderneming verschilt daarin hemelsbreed van 'natuurlijke theologie' dat een 'theologie van de natuur' de wereld in relatie tot de handelende God verstaat en niet zoekt naar Godsbewijzen.

De theologische uitspraken die Johan Buitendag doet, herinneren theologen eraan dat zij in een publieke ruimte te midden van een koor van stemmen spreken die vanuit uiteenlopende academische disciplines ook claimen betekenisvolle uitspraken te (kunnen) doen hoe de werkelijkheid die wij ervaren geconstitueerd is. Bij zijn theologische beoordeling van situaties geeft hijzich geregeld ook rekenschap van bijvoorbeeld biologischeinzichten, van evolutietheorieën of van ethologische oordelen betreffende die toestanden. Ook godsdienst-filosofische beoordelingen van kwantummechanische uitspraken over het universum waar wij deel van uit maken probeert hij in zijn oordelen te betrekken! Zijn opmerkelijke belezenheid blijkt uit de veelsoortige gesprekspartners die blijkens zijn publicaties hem met hun inzichten aanzetten zijn eigen opvattingen verder te ontwikkelen. Deze uitwisseling van ideeën en informatie dient voor

Note: Luco J. van den Brom is an extraordinary Professor of Systematic Theology at the University of Pretoria, South Africa. 
Buitendag uiteindelijk maar één doel: 'teologie moet terugkom aarde toe' (2013:1). Omdat theologische activiteiten niet geïsoleerd plaatsvinden, maar in een publieke ruimte, zowel maatschappelijk als academisch, kan theologie zich niet tot een internalistische bezigheid beperken, maar moet zij kerk, geloof en individuele spiritualiteit (als gelovig beleven) overstijgen om met de beide benen op de grond te staan. Daarbij dient de theologie samen met andere disciplines naar de hele waarheid ('the truth of the whole') te zoeken ten behoeve van een verdeelde en verscheurde wereld. Hierbij verwijst Buitendag instemmend naar Jürgen Moltmann. 'The truth of the whole' is een Engelse vertaling van 'die Wahrheit des Ganzen' (Moltmann 2003:7). Hoe begrijpt Buitendag deze ambigue notie van 'the truth of the whole'? Buitendag en Moltmann blijken bij 'the truth of the whole' niet helemaal in dezelfde richting te denken.

\section{Moltmanns idee van 'de hele waarheid'}

Waarheid heeft van doen met uitspraken over een stand van zaken, een gebeurtenis, voorvallen, of over een proces van veranderingen in de werkelijkheid waarvan wij deel uitmaken. Zo zeggen wij wel dat het waar is dat de zwaartekracht op de maan een zesde is van die op aarde, en dat op 20 juli 1969 Neil Armstrong als eerste mens een voet op de maan zette. Waaraan moeten wij nu denken bij 'the truth of the whole'? Moltmann spreekt zelf over 'die Wahrheit des Ganzen', waarbij hij op de conflicten tussen geloofsuitspraken en natuurwetenschappelijke oordelen wijst die in de 16e en 17e eeuw werden opgelost door middel van een boedelscheiding. In die tijd oordeelden diverse denkers dat (christelijk) geloof primair zich richt op wat voor mensen persoonlijk als heil van belang is, terwijl de toenmalige natuurwetenschappen daarentegen door rationele analyse van waarnemingen en experimenten een objectief beeld van onze tastbare werkelijkheid verwerven. Godsdienst en theologie bewegen zich in deze visie dus op een ander terrein dan waarop de natuur- en scheikunde hun waarheidsoordeel uitspreken. Naar het oordeel van Moltmann heeft de theologie toen zij die boedelscheiding tussen een innerlijke werkelijkheid en een tastbare werkelijkheid aanvaardde, een belangrijk inzicht losgelaten dat 'die Wahrheit immer eine sei und die Wahrheit des Ganzen sein müsse'. Dientengevolge verwacht(te) de theologie ook geen compleet heil (ein ganzes Heil) of heil voor de hele werkelijkheid (das Heil des Ganzen), want zij betrekt 'heil' op het innerlijk van de mensen. Impliciet zegt Moltmann daarmee dat dergelijke vormen van theologie vergeten dat mensen meer zijn dan hun innerlijk, namelijk lichamelijk. Heil voor mensen heeft betrekking op de hele mens, innerlijk èn uiterlijk, niet enkel voor de 'ziel', maar voor lichaam èn ziel (Moltmann 2002:17-18).

Wat betekent nu de uitspraak dat 'die Wahrheit immer eine sei und die Wahrheit des Ganzen'? Indien dit ook op de waarheid van uitspraken over het geheel van onze werkelijkheid betrekking heeft, dan past dat bij een streven naar een allesomvattende theorie die bovendien ook waar blijkt te zijn ('theory of everything'). Moltmann noemt zelf een dergelijk positivisme een naïef geloof, even naïef als wat het vroegere mythisch-theologisch wereldbeeld vertolkte, omdat positivisten van mening zijn dat de werkelijkheid dusdanig geconstitueerd is als de wetenschap middels haar experimenten heeft laten zien: 'eine Deckungsgleichheit von Wissenschaft und Wirklichkeit' (Moltmann 2002:22-23). De natuurwetenschappelijke benaderingswijze concentreert zich methodisch op onderdelen van processen en objecten, probeert die te beschrijven, te ordenen en te verklaren. Dat houdt in dat wetenschappers hun onderwerp steeds vanuit een bepaald perspectief bestuderen en in een kader van specifieke theorieën beschrijven om met reproduceerbare experimenten de juistheid van hun conclusies te kunnen staven. Wetenschappelijk is het echter een misvatting te menen dat natuurwetenschappelijke waarheidsoordelen die methodisch op specifieke perspectivische inperkingen gebaseerd zijn, 'die absolute Wahrheit des Seins' zouden kunnen heten. Betekent de 'absolute Wahrheit des Seins' zoiets als de correcte beschrijving van de bestaande, ons omgevende, werkelijkheid, dan wijst Moltmann mijns inziens terecht op een wetenschappelijk onoverkomelijk probleem voor het positivistisch perspectief (Moltmann 2002:23-27). Menselijke waarnemers, ook in teamverband samenwerkende onderzoekers, beschikken immers niet over een positie om zich een compleet beeld van de omringende werkelijkheid te kunnen vormen; mensen staat een 'God's eye point of view' niet ter beschikking.

Terwijl Moltmann inziet dat het onmogelijk is om zinvol over absolute wetenschappelijke waarheid te spreken, ziet hij wel weer de mogelijkheid om de vraag naar 'de waarheid en het heil van het geheel' opnieuw te stellen. Hij zegt het Hegel na dat 'Das Wahre ist das Ganze' en merkt zelf daarbij op dat het geheel van de werkelijkheid zich aan ons kennen onttrekt, maar hij lijkt een idee van dat 'geheel van de werkelijkheid' te hebben. Moltmann stemt immers met Goethe in dat aan alle verschijnselen en partiële kennis 'jenes dunkle Totum' ten grondslag ligt, waardoor wat er ook in de levende natuur gebeurt, dit in relatie staat tot het 'Ganze' van de werkelijkheid. Van dit 'vage' geheel van de werkelijkheid weet Moltmann te zeggen dat het niet achter alle gebeurtenissen bestaat, maar als een afgerond geheel op dit moment zelfs ook nog niet kan bestaan, want het beweegt zich in het historisch proces naar een toekomstig geheel (Moltmann 2002:27-28). Blijkbaar kan het geheel van de werkelijkheid achteraf vanuit een toekomstige definitieve afloop van dit historisch proces wel gekend worden. Moltmann doet hier over 'jenes dunkle Totum' wel feitelijke uitspraken in temporele termen waarbij hij veronderstelt dat wij met het begrip 'tijd' niet enkel een lokaal proces binnen dit grotere geheel, maar ook een bepaalde structuur binnen dit 'totaal' kunnen bespreken, zelfs al noemt hij dit 'Totum' vaag. Zolang de ons omringende werkelijkheid zich in haar historisch proces naar haar uiteindelijke toekomst verder ontwikkelt, blijft het - gegeven Moltmanns voorstelling van 'das Ganze' - ook wetenschappelijke kennis steeds aan haar begrensdheid herinneren. Intuitief kunnen we ons misschien wel een voorstelling van dit 'totaal' in zijn ontwikkeling maken, maar het blijft vaag. 
Echter ook natuurwetenschappers zoals bijvoorbeeld Paul Davies kunnen speculaties over het 'totaal' ontwikkelen in termen van bijvoorbeeld een meer-dimensionele superruimte waarin verschillende werelden naast elkaar kunnen bestaan met tegenovergestelde verleden-toekomst oriëntaties (Davies 1990:92-106, 194-197). In deze meerdimensionele super-ruimte kan men Moltmanns voorstelling van 'das Ganze' als een parallelle wereld denken naast vele andere werelden. De vraag komt dan op wat wij met het 'totaal' bedoelen: betreft dit 'totaal' de ons omringende werkelijkheid in haar historische ontwikkeling of gaat het over een super-ruimte met daarin alle mogelijke werelden? Het is opmerkelijk dat Moltmann wel naar Werner Heisenberg verwijst (die in 1925 de wiskunde van de kwantummechanica ontdekte) maar zelf met verschuivingen in het wereldbeeld door inzichten uit de kwantummechanica niets van doen lijkt te hebben: het 'totaal' blijkt voor hem een eschatologisch begrip voor een alomvattend proces met een toekomstgerichte oriëntatie waarvan de afloop nog openstaat. Voor de zin van de geschiedenis heeft de christelijke theologie volgens Moltmann steeds te bedenken dat met Christus' kruis en opstanding het 'einde van de geschiedenis' in Gods toekomst in het vooruitzicht is gekomen. Daarmee komt het Koninkrijk van God aan de orde met het oog op het verhoopte toekomstige heil voor de wereld (Moltmann 2002:29-31).

Hierbij valt het op dat Moltmann niet over 'geschiedenis', maar over 'de geschiedenis', met een bepaald lidwoord, spreekt. Dit gebruik suggereert alsof er zoiets als de gang der gebeurtenissen in het algemeen bestaat, terwijl 'de geschiedenis' als abstract begrip of paraplubegrip functioneert. Wij kennen het concrete gebruik van 'geschiedenis' als een genitief-begrip, als de geschiedenis van concrete personen en zaken. Zo spreken we over de geschiedenis van Jezus van Nazareth, van het volk Israël, van het antieke Rome, van de Tachtigjarige Oorlog, van de Russische leiders in de Tweede Wereldoorlog, van de landstreek van Bourgogne, enzovoort. Historici vertellen daarbij over hun onderwerp concrete verhalen die in een wirwar van concrete sporen uit een verleden concrete verbanden tekenen waarin concrete mensen handelen. Zij schrijven evenwel geen 'geschiedenis in het algemeen', waarin zij alle menselijke handelingen samen met alle andere gebeurtenissen 'tussen hemel en aarde' in een geheel omvattend verband zouden hebben geplaatst. Intuitief kunnen wij met Moltmann bij 'de geschiedenis' ons misschien wel iets voorstellen als de optelsom die verhalend alle menselijke handelingen beschrijft samen in de context van alle andere gebeurtenissen in die bepaalde periode waarin er mensen bestaan. Net als met Moltmanns voorstelling van 'das Ganze' wordt ook een omvattend beeld van 'de geschiedenis' te omvangrijk, ongrijpbaar en te vaag om ook maar narratief te kunnen hanteren.

We hebben ons rekenschap te geven hoe geschiedfilosofen het gebruik van de term 'geschiedenis' beoordelen. De geschiedfilosoof W.H. Walsh merkt bijvoorbeeld op dat wij het woord 'history' dubbelzinnig hanteren, omdat wij het enerzijds wel betrekken (1) op een nauwkeurige beschrijving van wat wij van menselijke handelingen uit het verleden hebben kunnen waarnemen en anderzijds (2) op het verhaal dat wij daarbij van die waarnemingen construeren als resultaat van een historisch denkproces. Bovendien wijst hij erop dat historici het menselijk verleden bestuderen en zich niet met een geologisch verleden bezighouden. Geeft de ene historicus als chroniqueur een precieze beschrijving van wat er zoal gebeurde (d.i. 'a plain narrative'), de ander probeert juist gebeurtenissen ook te verklaren waarom zij plaatsvonden. Deze laatste historicus beoogt 'a significant narrative' te verschaffen waarmee hij ons als lezers wil laten zien waarom iets gebeurde (Walsh 1967:31-33). Het 'verleden' fungeert hier als de veelheid aan menselijke activiteiten in een bepaalde periode, terwijl 'geschiedenis' betrekking heeft op dat wat historici over dat verleden schrijven. Dientengevolge is 'geschiedenis' (history) in principe een nooit voltooid narratief proces, want om een 'significant narrative' voor een bepaalde periode te leveren proberen historici vanuit bepaalde relevante perspectieven (zoals eertijds relevante sociale, economische, culturele, religieuze motieven en ideeën) tussen uiteenlopende gebeurtenissen verbanden aan te geven waardoor deze samen als een geheel proces in die periode zouden kunnen worden verteld. Bij een dergelijk opmerkelijk narratief voorstel voor verbanden lijkt het waarschijnlijk dathistorici ook andere relevante perspectieven naar voren kunnen brengen in een discussie over welke perspectieven meer relevant zijn of in bepaalde (rang-)orde gecombineerd zouden moeten worden met het opmerkelijk narratief voorstel. Daarom suggereert John Arnold terecht dat historici pas de verklaring van bepaalde gebeurtenissen kunnen leveren als eind van alle discussie daarover. Geschiedenis bestaat niet buiten de historici, maar historiografie als activiteit verschaft ons pas 'geschiedenis'. (Arnold 2000:pos. 352-355; 1292-1296). Natuurlijk leveren historici geen willekeurige interpretaties van de hun beschikbare evidentie voor wat er ooit ergens zou zijn gebeurd, maar zij laten ruimte voor een serieuze discussie over wat zij menen dat voor redelijk denkende mensen daarin als 'objectief' aanvaardbaar verhaal toeschijnt. Volledige objectiviteit is in de geschiedwetenschap ook niet mogelijk omdat een volledige weergave van een overzicht van de wereld daar en toen vanuit een God's eye point of view voor eindige historici logisch niet bereikbaar kan zijn. Daarom noemt Michael Stanford, als geschiedfilosoof, objectiviteit een regulatief ideaal voor historici, want zij weten vaak niet of zij wel over voldoende evidentie beschikken. Wat hun op basis van sporen en overblijfselen evident voor hun voorstelling van zaken toeschijnt, kan naar het oordeel van andere deskundigen anders bezien worden: 'History, like hunting, geology, ... rests on judgements. In all these cases the judgements ... are not infallible' (Stanford 1998:54-64). Bij deze beoordelingen beïnvloeden ook hun eigen interesses, waarde- en vooroordelen onderzoekers waarop zij primair attent zijn. 
Het verleden is voorgoed voorbij en bestaat als zodanig niet meer in onze leefwereld, maar sporen of overblijfselen herinneren ons soms nog daaraan. Te denken valt aan geologische sporen, documenten, monumenten, overgeleverde herinneringen, gebruiksvoorwerpen of afbeeldingen. Mijn stelling luidt dat geschiedenis niet anders bestaat dan als een narratief voorstel hoe wij via een beredeneerd samenhangend verhaal in die sporen betekenisvolle patronen zouden kunnen aangeven. Dergelijke narratieve voorstellen kunnen helpen om met sporen die aan een verleden herinneren te kunnen omgaan. De geschiedfilosoof Herman Paul wil over de 'historische werkelijkheid' spreken als de gang van gebeurtenissen (historia res gestae), met name als een stand van zaken die 'bestond' (NB) op een tijdstip dat al lang verstreken is (Paul 2014:39). Mijns inziens betreft een dergelijke stand van zaken een geconstrueerd beeld van de omstandigheden op een bepaald moment eertijds. Wat betekent hier 'werkelijkheid' nog? Zo vertellen historici een samenhangend verhaal hoe zij in een wirwar van overgebleven sporen die als effecten lijken te wijzen op vroegere gebeurtenissen van oordeel zijn verbanden en patronen te kunnen aangeven. Daarvan claimen zij dat die patronen, structuren en gereconstrueerde processen in werkelijkheid hebben bestaan: deze standen van zaken bestonden, maar momenteel bestaan zij niet meer. Met het begrip 'werkelijkheid' bespreken wij het bestaan van zaken en van hun verschijning als bepalend voor onze handelingsmogelijkheden. Kunnen wij bij standen van zaken die bestonden nog wel over werkelijkheid spreken, als die niet bestaat? Enkel een ideale waarnemer die in dat verleden van die standen van zaken zou kunnen verkeren kan dat samenhangend verhaal beamen. Deze ideale waarnemer levert Stanfords genoemde objectiviteit en realiseert het regulatieve ideaal, maar ook deze waarnemer heeft de status van een constructie. Waarom zouden we dit werkelijkheid noemen? Daarmee claimen we iets als werkelijkheid voor de status van de gereconstrueerde voorgeschiedenis van werkelijk aangetroffen sporen en overblijfselen, maar zeggen dan met zoveel woorden dat ons samenhangend verhaal (over de voorgeschiedenis) klopt. Paul wil waarschijnlijk uitsluiten dat men van alles zinvol over het verleden zou kunnen beweren en mensen van alles toedichten. Dat is een respectabel standpunt voor een historicus. De postmoderne geschiedfilosoof Keith Jenkins (2003:10-11) herinnert mij eraan dat 'we read the world as a text, and, logically, such readings are infinite', maar wij zijn niet in staat onze lezing nu aan een 'werkelijk bestaand verleden' te toetsen, laat staan geschiedenis als object aan te wijzen. Hooguit kunnen wij onze lezing van wat er gebeurd kan zijn als redelijke interpretatie van bestaande sporen aanbieden. Vanwege dit oneindig aantal mogelijke interpretaties, terwijl geldt dat niet elke interpretatie zondermeer een redelijke mogelijkheid is, blijf ik bij mijn elders breder verdedigde stelling 'Geschiedenis bestaat niet!' (Van den Brom 2014:335-364) Het betreft reconstructies aan de hand van aangetroffen sporen.

Op grond van de stelling dat 'geschiedenis niet bestaat', meen ik dat Moltmanns gedachte dat met Christus' kruis en opstanding het 'einde van de geschiedenis' in Gods toekomst in het vooruitzicht is gekomen, uiteindelijk een weidse en romantische beschouwing vormt over 'das Ganze der Wirklichkeit' in het proces van 'de geschiedenis'. Dit lijkt een holistische visie om 'das Ganze der Wirklichkeit' aan de orde te stellen, maar dergelijke abstracte termen als 'das Ganze', 'die Wahrheit des Ganzen' en 'de geschiedenis' roepen een wereldbeeld op waarover wij intuïtief wel kunnen speculeren, maar waarvan wij logisch geen overzicht kunnen hebben, want als mensen maken wijzelf deel uit van dat 'totaal': wij bevinden ons 'binnen' en niet 'boven' het totaal. Dit totaal komt eschatologisch in beeld, maar bestaat in het heden niet, zodat dit toekomstig geheel hier en nu geen holistisch perspectief kan leveren.

\section{Buitendags theologiebegrip}

Buitendag beschouwt theologie als een 'komprehensiewe onderneming' om in gesprek met andere disciplines tot een omvattend begrip van de werkelijkheid te komen. Hij valt Moltmanns uitspraak bij dat theologie 'with all others ... may search for the truth of the whole' (Buitendag 2013:1). Buitendag zoekt een theologische grammatica om de werkelijkheid 'komprehensief' te verstaan door zich rekenschap te geven van wat andere academische disciplines aan dat verstaan voor het theologisch spreken kunnen bijdragen. Dit theologisch spreken beperkt zich niet tot binnenkerkelijke en existentiële vraagstukken, maar probeert zoveel mogelijk bewust zowel kosmologische als binnenwereldlijke uitspraken van andere disciplines te becommentariëren en vervolgens te verdisconteren. Mijn vraag luidt: Sluit Buitendags idee van theologie als 'komprehensiewe onderneming' aan bij Moltmanns gedachtegangen?

'Komprehensief verstaan' begrijp ik als een veelomvattende poging om niet-theologische inzichten die wij als redelijk voor onze rekening nemen, ook als relevant in onze theologische en spirituele beoordelingen verwerken. Deze veelomvattende pogingen kunnen leiden tot een 'onderneming wat holisties neig', wanneer men naar een samenhangend netwerk tussen de verschillende theologische en niet-theologische uitspraken streeft. Daarbij is van belang te beseffen dat afzonderlijke uitspraken hun betekenis ontlenen aan hun plaats in dat gehele netwerk van aanvaarde overtuigingen en inzichten. Holisme wordt hier analoog aan inzichten van Quine gebruikt, dat de betekenis van (empirische) volzinnen ligt in hun plaats binnen een heel verband of systeem van volzinnen (Quine 1981:70-71). Quine geeft hier een aanscherping van Wittgensteins inzicht dat een volzin en niet een individueel woord de kleinste betekeniseenheid vormt. Theologie is nu een 'holistische onderneming' in haar streven naar een betekenisgevend netwerk van theologische en niet-theologische uitspraken. Een dergelijke holistische theologie verschilt duidelijk wel van Moltmanns zoeken met anderen naar de waarheid van het totaal (die Wahrheit des Ganzen). Het Moltmanniaanse 'totaal' is het geheel van de werkelijkheid zoals uiteindelijk deze eschatologisch in Gods perspectief 'van bovenaf' gezien en gekend wordt. 
Daarentegen heeft waarheid in Buitendags genoemde holistische zin betrekking op betekenis-samenhang binnen het gehele netwerk van door theologen (en gelovigen) als redelijk aanvaarde overtuigingen en inzichten: het geheel bezien vanuit dat web van huidige overtuigingen, dus 'van onderaf'. Quine spreekt hier van een 'moderate' of 'relative' holisme. Buitendags holisme heeft meer weg van die relatieve denkvorm, omdat hij vanuit een besef van gesitueerd te zijn in sociale en natuurlijke netwerken over Gods aanwezigheid wil spreken, dat is vanuit de menselijke habitat (Buitendag 2013:2). Moltmanns 'Ganze' betreft daarentegen de totaliteit van de werkelijkheid waarvan de voltooiing nog aanstaande is: voor mensen kan een dergelijk holisme in retrospectief geen betekenis hebben voor een oordeel over de huidige stand van zaken (Moltmann 2002:28). Voor Buitendag en Moltmann betekent 'the truth of the whole' dus iets geheel anders.

Moltmanns 'Wahrheit des Ganzen' veronderstelt immers een correspondentietheorie van waarheid in eschatologisch retrospectief, terwijl Buitendag voor 'the truth of the whole' van huidige wetenschappelijke inzichten een coherentietheorie gecombineerd met een pragmatische theorie van waarheid behartigt. Hij zoekt naar intrinsieke waarheden omtrent de empirische wereld welke gelovigen als relevant beschouwen voor hun begrip van die werkelijkheid en op basis waarvan een dialoog mogelijk wordt met natuurwetenschappers, omdat zij die ware proposities als empirisch intrinsiek herkennen. Deze intrinsiek empirische waarheden worden in de praktijk van de geloofsbeleving waargenomen en opgemerkt als relevant voor de godsdienstige situering in en beleving van die empirische proposities. Zo ziet Buitendag bij sociaal levende insecten een interessante en religieus relevante vorm van leven om naar gemeenschappen als fundamenteel gegeven te kijken. In Spreuken 6:6 krijgen mensen de wegen van de mier voorgehouden, waarbij Buitendag zich afvraagt of deze mierenwegen enkel een morele prescriptief tot vlijt inhouden: hij ziet hier mieren in hun natuurlijke biotoop 'communaal of corporatief' functioneren wat als relevant paradigma voor de waarneming van fundamentele principes in de biologische werkelijkheid kan dienen. Van deze werkelijkheid maken ook mensen deel uit: zij functioneren ook communaal en hebben een corporatieve identiteit.

\section{Epistemologische ellips van Buitendag}

Buitendag beklemtoont dat de theologie voor haar holistisch getinte uitspraken ernaar moet streven ook de kosmologie in haar spreken te betrekken om de reikwijdte en rijkdom van het Godsbegrip te verwoorden. Hij gebruikt daarbij als denkmodel een beeld uit de vlakke meetkunde: de ellips, die twee brandpunten heeft. Een ellips is de baan van een punt waarvan de som van de afstanden tot die twee vaste punten constant is. Buitendag kiest opvallend genoeg voor een ellips als denkmodel en niet voor een cirkel: die heeft één middelpunt. Voorbeelden van theologische vormen waarin de cirkel als denkmodel staat, zijn de christologische structuur van de theologie van Karl Barth en van Bram van de Beek: hun theologie concentreert zich op en rond de figuur van Jezus Christus. Buitendag benoemt de brandpunten van de ellips als zijn theologisch denkmodel met a) ontologisch en b) epistemologisch. Hierbij spreekt de theologie over de betekenis of waarde van intrinsieke waarheden uit de empirische wereld voor het werkelijkheidsbeeld van het christelijk geloof voor een mogelijke dialoog met natuurwetenschappers die deze waarheden als empirisch intrinsiek herkennen. Ontologisch zijn natuurwetenschappers en theologen het met elkaar eens over deze intrinsieke waarheden, maar zij zijn epistemologisch langs verschillende wegen bij 'de mier' uitgekomen.

Het beeld van de ellips als denkmodel herinnert aan het beeld van de 'handen van God' dat Irenaeus gebruikt om over Gods activiteiten jegens mensen te spreken: deze staan voor Jezus Christus en de Heilige Geest. Daarmee geeft Irenaeus aan dat wij over God steeds als God-Drie-enig hebben te spreken. In Adversus Haereses 4.praef.3 schrijft hij: 'De mens werd gemaakt in de gelijkenis van God en gevormd door de Handen van God, dat is, door de Zoon en de Geest tegen wie Hij zei: "Laat ons mensen maken."' Door zo over God als God-Drie-enig te spreken dringt Irenaeus niet aan op een christologische concentratie, dus op Gods openbaring eertijds in Jezus Christus binnen het kader van de Hebreeuwse Bijbel. God hebben wij in het heden aan het werk te zien, als in een pneumatologisch perspectief. 'Adam ontkomt nooit aan Gods Handen ..., maar naar het welbehagen van de Vader vervolmaken zijn Handen een levend mens, opdat Adam in het beeld en gelijkenis van God zou worden' (Adv. Haer. 5.1.3). John Behr merkt bij deze passage op dat deze Handen mensen vormen en voorbereiden om het leven van God te leven als een nieuwe geboorte door de levendmakende Geest (Behr 2013:151). Gods daadwerkelijke betrokkenheid bij deze wereld wordt hier juist ook pneumatologisch verstaan.

Dit pneumatologisch verstaan van Gods betrokkenheid bij onze wereld kunnen wij goed met de woorden van wijlen Arthur Peacocke aanduiden: 'the immanence of God as creator "in, with and under" the natural processes of the world unveiled by the sciences'. Buitendag gebruikt dit citaat van Peacocke die hier sacramentele terminologie hanteert. Bij die sacramentele terminologie merkt Peacocke op dat de kerk in de sacramenten 'entities, structures and processes' uit de natuurlijke wereld opneemt en hen een functie van een goddelijke instrument toekent. Daarmee bewerkstelligt God bij de deelnemers veranderingen die passen bij de situatie waarin zij verkeren, veranderd (aangesproken) door het Christus-gebeuren. Dit sacramentele verstaan van de wereld vat Peacocke op als de holistische betekenis van Gods genadig handelen in diens communicatie met de mensheid in onze wereld (Peacocke 1993:339-342). Het epistemologisch brandpunt van Buitendags theologische ellips geeft ruimte aan om Gods mogelijke betrokkenheid op te merken in 'entities, structures and processes' van de natuurlijke wereld waarin wij zijn ingebed. 
Zoals ik hem begrijp, gaat het Buitendag uiteindelijk niet om een rationeel argument voor Gods bestaan op grond van wat er valt op te merken in de natuurlijke wereld, maar om de ons omringende leefwereld te verstaan als een communicatiemiddel in Gods hand. In het perspectief van gelovigen krijgen die entiteiten, structuren en processen waarover Arthur Peacocke spreekt en die ook niet-gelovige natuurwetenschappers kunnen beschrijven, mogelijk een godsdienstige betekenis die de empirische waarneming spiritueel transcendeert. De leefwijze van de mier van Spreuken 6 levert hem een model of paradigma om de ons omringende werkelijkheid te begrijpen als iets dat laat zien van het belang om corporatieve concepten te gebruiken. Het is wetenschappelijk evident dat mieren in gemeenschappen leven en daarbinnen hun rol spelen waarbij duidelijk wordt dat deze mieren niet als individu op zichzelf, maar alleen als inherent deel van het volk (de mierenstaat) kunnen bestaan. Een mierenstaat of een bijenvolk kunnen we antropomorf bespreken door de 'koningin' als de 'ziel' of het 'brein' van de betreffende staat te kwalificeren. Het is een manier van kijken naar een bepaalde mier, termiet of bij die door anderen met de 'eierenlegmachine' aangeduid wordt.

Analoog aan de relatie van de mier tot de mierenstaat kan men de mens in een menselijke samenleving ter sprake brengen: mensen bestaan niet op zich, maar als deel van een gemeenschap. Zo kan men ook over de menselijke persoon spreken als brein in een menselijk lichaam dat deel uitmaakt van een gemeenschap die op haar beurt zich weer in een netwerk met een natuurlijke habitat bevindt. Dit zijn voorbeelden waarin onderlinge relaties voortdurend aan de orde worden gesteld: illustraties van een relationeel denkmodel dat bij alle zaken naar de relevantie van hun relaties vraagt. De centrale vraag bij dit relationeel denkmodel luidt: zijn relaties ontologisch gezien primair of secundair? In het licht van de Cappadocische triniteitsleer, zoals uiteengezet door John Zizioulas, is 'gemeenschap' de fundamentele denkcategorie: 'het ontologisch "principe" van God is de Vader' (Zizioulas 1985:41). De persoon van de Vader verwekt uit liefde de Zoon en brengt de Geest voort en zo is de Vader de 'oorzaak' van de gemeenschap die de Heilige Drieeenheid is. Deze Drie-eenheid als gemeenschap is ontologisch het oer-concept zonder welke wij niet van Gods bestaan kunnen spreken, anders gezegd: 'The being of God is a relational being' (Zizioulas 1985:16-17). Bij deze denkwijze sluit Buitendag zich aan door een netwerk tussen Schepper en schepping te denken dat door 'liefde' als een persoonlijk begrip wordt getypeerd. Hoe kan hij hierbij Gods immanentie in de geschapen werkelijkheid ter sprake brengen?

\section{Pan-en-theïsme}

Voor Gods actieve immanentie in de geschapen werkelijkheid gebruikt Buitendag een moderne voorstelling als het pan-entheïsme. Met dit model wil hij de klassieke voorstelling van een afhankelijkheidsrelatie tussen de (contingente) schepping en de transcendente Schepper (als de noodzakelijke God) vermijden: de schepping is in God, maar niet buiten God te denken. Daarvoor denkt hij pan-en-theïsme te kunnen gebruiken in lijn met voorstellingen van Arthur Peacocke over een model van interacties binnen complexe systemen tussen een deelsysteem (lower subsystem) en een overkoepelend systeem (system-as-a-whole). Binnen dynamische complexe systemen (fysisch, chemisch, biologisch, neurologisch) kan het gedrag van een systeem als geheel causaal van onderaf beschreven worden vanuit eigenschappen en processen van de samenstellende onderdelen van een systeem ('bottom-up' causaliteit). Dit is de gangbare procedure in de natuurwetenschap. Er zijn echter situaties bekend waarbij een systeem als geheel het gedrag van zijn samenstellende subsystemen in een bepaalde richting aanstuurt ('top-down' causaliteit). Deze ingewikkelde verschijnselen verschaffen ons een model om over het handelen van God in interactie met onze wereld te spreken met behulp van de gedachte dat de wereld-als-eengeheel als 'in God' te beschouwen is, zodat Hij aan de wereldals-een-geheel alsmede aan haar samenstellende onderdelen tegenwoordig is. Dit kunnen we Gods immanente tegenwoordigheid noemen. Wanneer we God hierbij denken als betreft het hier een erbij komend niveau ('supervenient') van het geheel, dan kunnen wij Hem als 'top-down' actief in de wereld-als-geheel denken, zonder dat God natuurwetten of natuurlijke regelmatigheden schendt. God is daarbij niet identiek met, maar 'meer dan' de wereld (Peacocke 1986:99, $131 ; 1993: 53-55,157-160,370-372)$. De analogie hierachter is de eenheid van de menselijke geest met ons brein dat topdown ons menselijk lichaam beïnvloedt. Peacocke doet dit top-down voorstel als model hoe we Gods handelen kunnen denken, maar hij geeft toe dat alleen God zelf de ervaring van de wereld-als-een-geheel heeft (Peacocke 1993:163-164); mensen kunnen daarvan ook geen besef hebben omdat zij niet over een 'God's eye point of view' beschikken. Daarbij gebruiken Peacocke en anderen het begrip 'emergentie'.

Van Roger Scruton komt het idee dit begrip 'emergentie' als volgt inzichtelijk te maken. Neem een schilderij van bijvoorbeeld Vincent van Gogh. Kijken we ernaar dan zien we penseelstreken als toetsen verf op een linnen doek en realiseren ons vervolgens ineens dat het gezicht van Vincent vanaf het doek in de penseelstreken ons aankijkt; dit gezicht is niet een extra eigenschap van het doek, evenmin van de verf, maar het komt op uit de configuratie van het vlakke doek en de verfstreken, als een emergente eigenschap ervan (Scruton 2004:222-223). Men gebruikt emergentie ook wel om te verhelderen dat bij complexe (bio-)fysische processen een deze overstijgend verschijnsel kan optreden dat niet uit die onderliggende processen herleidbaar is maar daardoor gedragen wordt (Peacocke 1986:28-30; 1993:62; Buitendag 2013:6). Een bekend voorbeeld vormen de activiteiten van de menselijke geest die door processen in ons brein (= ons lichaam) gedragen worden maar daarmee niet identiek zijn. Het lichaam heeft wel invloed op de activiteiten van de menselijke geest, maar is zelf op zijn beurt ingebed in een bredere omgeving van biochemische processen en biologische factoren; daarmee wordt de menselijke verschijning niet als individu op zich beschouwd, maar bezien in een netwerk 
van allerlei andersoortige relaties tot grotere (sociale, biologische, fysische, informatieve) gehelen.

'Emergentie' helpt bijvoorbeeld activiteiten van de menselijke geest te bespreken in zijn relatie tot zijn lichamelijke karakteristieken, en zo kan op analoge wijze 'pan-en-theïsme' met behulp van hetzelfde begrip 'emergentie' proberen de relatie van God en de schepping bespreekbaar te maken. Hier speelt wel de vraag met welke bedoeling theologen en godsdienstfilosofen het pan-en-theïsme als model voor het spreken over de betrokkenheid van de handelende God bij de processen in de menselijke leefwereld willen gebruiken. Is het hun bedoeling om door het model pan-en-theïsme met het begrip 'emergentie' het spreken over Gods handelen in de wereld begrijpelijk dan wel plausibel te maken? Willen wij een uitspraak voor iemand begrijpelijk maken, dan spannen we ons in om die uitspraak aan die ander helder of inzichtelijk te presenteren en leggen de bedoeling ervan uit. 'Begrijpelijk maken' kunnen we een hermeneutische activiteit noemen. Om een uitspraak plausibel te maken, dragen wij argumenten aan waarom zij als stelling ons geloofwaardig of aannemelijk toeschijnt, in de veronderstelling dat zij als stelling of bewering wel begrijpelijk is. Dit is nu juist een kentheoretische activiteit. Beide activiteiten veronderstellen een talige gemeenschap, terwijl kentheoretische aanvaardbaarheid berust op wat kennis op een bepaald moment voor een gemeenschap inhoudt. Buitendag streeft ernaar de talige en de kentheoretische activiteiten bij elkaar te houden en te laten convergeren: natuurwetenschappelijke inzichten relateren aan christelijk geloof en theologie.

\section{Waarom pan-en-theïsme?}

In zijn theologische reflecties waarschuwt Buitendag voor de verleiding van supranaturalisme dat een dualisme voorstaat waarin God en de geschapen werkelijkheid als van elkaar gescheiden sferen worden gedacht. In een supranaturalistische visie op de ons omgevende werkelijkheid kunnen mensen voor een zinvol leven op twee verschillende manieren op een spirituele werkelijkheid een beroep doen: (1) een werkelijkheid die naast de fysieke werkelijkheid als 'geest' bestaat of (2) een werkelijkheid die de fysieke wereld transcendeert: 'God'. De eerste manier is een immanent supranaturalistische visie te noemen: de spirituele werkelijkheid is immanent aan de materiële werkelijkheid te denken. Daarbij kunnen gelovigen een dichotomisch mensbeeld hanteren: mensen zijn lichamelijk en hebben een 'ziel'. De tweede manier kan men een transcendent supranaturalistische visienoemen: de spirituele werkelijkheid transcendeert de materiële werkelijkheid. Daarbij relateren gelovigen de zin van hun leven aan de transcendente (externe) God. Mijn probleem met dergelijke vormen van supranaturalisme is dat $\mathrm{zij}$ een ontologisch dualisme verdedigen met behulp van een dubbeldekker wereldbeeld: God in de hemel (zijn eigen wereld) en wij schepselen (mensen, dieren en dingen) op de aarde. Dit ontologisch dualisme suggereert alsof wij over een extern overzicht beschikken waarin het geheel van God en onze wereld verschijnt als in een Archimedisch perspectief, dat logisch als een 'God's eye point of view' functioneert.

In een supranaturalistisch wereldbeeld verschijnt God de Schepper als bijkomstig complement van een naturalistisch werkelijkheidsbeeld (NB). Vanuit het bovengenoemd Archimedisch perspectief zien wij namelijk God in zijn eigen afdeling, 'de hemel', scheppend bezig de fysieke ruimte, de andere afdeling van dit dubbeldekker wereldbeeld, te vullen als was Hij (temporeel) de oorsprong van die materiële invulling. De wereld als schepping heeft geen oorsprong, maar is ex nihilo met de tijd geschapen! Dat betekent dat God de Schepper niet temporeel aan de schepping vooraf gaat, maar juist logisch voorop staat (Van den Brom 2011:9-10). 'Schepper' en 'schepping' zijn geen geïsoleerde onafhankelijke begrippen doch met elkaar gecorreleerd gegeven, waarbij Buitendag dan ook (terecht) opmerkt 'Skepper > skepping'! (Buitendag 2013:5)

Buitendag verkiest het pan-en-theïstisch model om over de Schepper in relatie tot de schepping te denken omdat dit een supranaturalistisch dualisme vermijdt en dus niet behept is met de logische problemen daarvan. Hij oriënteert zich op Phil Clayton als verdediger van een pan-en-theïstische positie. Een pan-en-theïstische positie bekijkt de wereld als 'wereld in God' terwijl God in een zekere zin ook de wereld transcendeert: zij bevinden zich niet op het zelfde vlak. Zo stelt Clayton: 'the world is contained within God; yet the world is not identical to God. Precisely this is the core thesis of panentheism' (Clayton 1997:90). In meer beeldende taal presenteert Jürgen Moltmann dit pan-en-theïsme alsvolgt aan ons: 'Um eine Schöpfung "außerhalb" seiner selbst zu schaffen, muß der unendliche Gott dieser Endlichkeit "in sich" zuvor Raum verschafft haben.' Daarbij stelt Moltmann zich voor dat de oneindige Drie-enige God, die als Vader, Zoon en Heilige Geest zo ruim is, dat de Drie-enige 'ergens' binnen de eigen trinitarische ruimte zichzelf inkrimpt: daar ter plekke kan de Drie-enige als het ware 'buiten zich' ruimte maken voor 'het niets' zodat de complete schepping ook ex nihilo binnen God zelf geschiedt (Moltmann 1980:123-125). Blijkbaar stelt Moltmann zich 'het niets' voor als iets (NB) dat in de Drie-enige God met 'lege ruimte' kan worden gerepresenteerd. Pan-en-theïsme zo voorgesteld, waarborgt dat de immanente God meer is dan wat er in de schepping empirisch valt waar te nemen, waarin Buitendags gedachte 'Skepper > skepping' dus wonderwel past. Met een dergelijk pan-en-theïstisch model is het mogelijk om een supranaturalistisch beschreven transcendentie van een panen-theïstisch beschreven transcendentie te onderscheiden als externe versus interne transcendentie. Buitendag opteert voor deze interne transcendentie.

\section{Problemen met pan-en-theïsme?}

Mijn vraag bij een dergelijk pan-en-theïstisch model luidt: als plastische metaforen helpen voorstellingen zoals 'de trinitarische ruimte' en 'de in zichzelf inkrimpende God' ons aan taal waarmee Gods activiteiten zouden zijn te bespreken, 
maar waarom zouden we deze beeldtaal als reality depicting voor de werkelijkheid van God moeten opvatten? De genoemde metaforen ('trinitarische ruimte', 'inkrimpende God') helpen ons een bekende tekst als 'Want in Hem leven wij, bewegen wij ons en zijn wij' (Hand 17:28) bespreekbaar te maken respectievelijk ons gedrag met onze attitude daarnaar te reguleren. Als schepsel bewegen wij ons als een ruimtelijk wezen in de geschapen ruimte welke zich volgens Moltmann in de voor ons door God 'ingeruimde ruimte' binnen de ruimte van Gods alomtegenwoordigheid bevindt. Met Newtoniaanse terminologie beschrijft Moltmann die ruimte van Gods alomtegenwoordigheid als de 'absolute ruimte', waarin Newtons eigen idee van 'absolute ruimte' (heel realistisch!) haar plaats ingeruimd heeft gekregen (Moltmann 1985:162-166). Terwijl wij mensen ergens binnen de geschapen ruimte leven, bewegen en bestaan, wordt vanuit die geschapen ruimte Gods wereld ruimtelijk geëxtrapoleerd. De vraag is ook hier: beschikken wij over een dergelijk overzicht om deze realistische claim betekenisvol te kunnen maken? Dat wil zeggen: kunnen wij als eindige wezens over ruimtelijkheid binnen de ook nog kwalitatief andersoortige oneindigheid van de ruimte van Gods alomtegenwoordigheid spreken in descriptieve volzinnen (reality depicting)? Kunnen wij daarbij het gebruik van metaforen vermijden wanneer we spreken van de schepselmatige ruimte waarvoor ruimte is ingeruimd binnen de ruimte van de Vader, de Zoon en de Heilige Geest als vormden zij de dimensies van de goddelijke alomtegenwoordigheid?

Phil Clayton herinnert lezers eraan dat oneindigheid in de wiskunde van oneindige verzamelingen door Georg Cantor onderverdeeld wordt in het materiële, het abstract gedachte en het Absoluut oneindige als limietgeval (Clayton 1997:90). Uit de wiskunde weet ik zelf dat de beide eerste verzamelingen transfiniet heten omdat zij als 'begrensd oneindig' kunnen toenemen, in tegenstelling tot het Absoluut Oneindige dat kwalitatief anders is, volstrekt volledig, niet-relatief, maar volledig onafhankelijk bestaat (in Deo). Een dergelijk Absoluut Oneindige is niet rationeel uit te denken. Clayton past dit toe op God die Absolute ruimte is en dus oneindige (geschapen) ruimten omvat. Hij meent op grond van de laatste onderscheiding te kunnen zeggen: 'it is possible to think of God as coextensive with the world: all points of space are encompassed by God and are in this sense "within" him.' Daarmee denkt hij God als transfiniet oneindig, want 'coextensive with' of van dezelfde omvang als de wereld die enkel transfiniet oneindig is. Terwijl hij enerzijds zegt dat (1) 'there is both identification or inclusion and distinction of God and world', stelt hij tegelijkertijd dat (2) 'yet the world is not identical to God' (Clayton 1997:90-91). Door (1) te poneren mist hij de notie dat God als de Absoluut Oneindige de transfiniet oneindige wereld binnen zich kan omvatten, maar daarmee juist niet te identificeren is! ('identification or inclusion' is een contadictio in terminis: identification $\neq$ inclusion vice versa.) Door de Absoluut Oneindige en een transfiniet oneindige wereld met elkaar te identificeren negeert Clayton dat Absoluut oneindig werkelijk absoluut verschilt van transfiniet oneindig, namelijk als kwalitatief anders. Door (2) te poneren creëert hij een contradictie en wordt zijn betoog betekenisloos vanwege dreigende incoherentie!

Clayton verdedigt een pan-en-theïstisch model voor de relatie God en de wereld naar analogie van de relatie geest en brein waarbij de goddelijke actor naar analogie van de menselijke actor wordt voorgesteld. Is er geen enkele analogie, dan wordt het woord actor dubbelzinnig. Deze dubbelzinnigheid wil hij wegnemen door over Gods handelen in de materiële wereld te spreken naar analogie van de wijze waarop de menselijke geest of het bewustzijn de materiële omgeving beïnvloedt. Daarom verdedigt hij dat bewustzijn, intentie en willen niet reduceerbaar zijn tot toestanden in het fysieke brein (Clayton 1997:240-243). Het zijn emergente eigenschappen, zoals we ook bij Peacocke zagen, waarmee Clayton twee problemen uit de philosophy of mind wil omzeilen: (1) Cartesiaans dualisme dat twee substanties in de mens poneert, namelijk 'denken' respectievelijk 'lichaam' naast elkaar; (2) fysicalisme dat veronderstelt denken of geest deel zijn van de fysische werkelijkheid. Hij denkt zich mentale eigenschappen als emergente eigenschappen die opkomen uit fysieke eigenschappen, maar daartoe niet reduceerbaar zijn. Deze mentale eigenschappen kunnen andere mentale toestanden veroorzaken, maar zouden bovendien in een 'down-ward causation' een fysiek systeem kunnen aansturen (Clayton 1997:252-258). Hij ziet een analogie tussen menselijke actoren en het persoonlijk optreden van de goddelijke actor die veranderingen in de fysieke wereld tot stand kan brengen.

Dit voorstel van Peacocke en Clayton voor een pan-entheïsme waarbij wij God per analogie als actor in de fysieke wereld kunnen denken, roept wel de vraag op of die wereld analoog nu ook Gods lichaam kan heten, met als consequentie dat God dan als mentale keerzijde een emergente eigenschap van de natuurlijke wereld zelf zou zijn! Dan moeten we vervolgens ons afvragen of God als de mentale keerzijde van dit lichaam nog logisch prioriteit heeft, dan wel daaruit in tweede instantie als secundair opkomt: is God als een emergente eigenschap dan met de natuurlijke wereld gegeven? Dit lijkt mij niet de intentie van het soort pan-entheïsme dat zij bepleiten. In zijn speculaties naar aanleiding van Cantors verzamelingenleer zagen we Clayton poneren: 'it is possible to think of God as coextensive with the world: all points of space are encompassed by God and are in this sense "within" him.' Mijn probleem betreft daar de vraag of men coherent van de Absoluut Oneindige kan zeggen dat Deze 'co-extensief' met de wereld is, dus met een transfiniete verzameling. Mogelijk past Clayton zijn Cantoriaanse reflecties daar reeds aan bij de gedachte van de wereld als Gods lichaam die wordt opgeroepen met het gebruik hierbij van het antropologisch model 'geest - lichaam'. Eerder wierp ik de vraag op of pan-en-theïsme met het begrip 'emergentie' als model bedoeld is om het spreken over Gods handelen in de wereld begrijpelijk dan wel plausibel te maken. Op de laatste pagina's van zijn boek maakt Clayton duidelijk dat 
pan-en-theïsme het spreken over Gods handelen in de wereld begrijpelijk probeert te maken als een hermeneutisch model: daar spreekt hij namelijk van 'the metaphor of the world as God's body' (Clayton 1997:264). Dit is echter juist niet meer 'reality depicting'!

\section{Theologie met relationele beelden}

Een metafoor draagt taal aan die suggereert of voorstelt dat wij een onderwerp X (hier: Gods handelen) op gepast wijze kunnen bespreken in termen van een ander, vertrouwder onderwerp Y (hier: menselijk handelen), al beseffen we ook dat $X \neq Y$. Een metafoor is een stijlfiguur die geen beschrijving van de werkelijkheid geeft, maar een verband creëert tussen $X$ en $Y$ met een voorstel hoe wij daarmee zouden kunnen omgaan. Het helpt ons te bepalen welke houding we tegenover gebeurtenissen of omstandigheden kunnen innemen. Buitendag verzet zich uiteindelijk tegen het gebruik van metaforen in ons spreken en denken omdat deze geen ontologische uitspraken doen, doch in beelden niet concreet zeggen 'soos die werkelijkheid dan kwansuis is' (Buitendag 2013:8). Hier ligt een serieuze vraag aan alle theologie: vertelt zij hoe uiteindelijk de werkelijkheid van God voor ons concreet is of hoe zij ons concreet aangaat? Is theologie een descriptieve aangelegenheid die zogezegd een afdoende beschrijving van de werkelijkheid nastreeft zoals die tussen hemel en aarde is?

Het is goed dat Buitendag theologen erop wijst dat theologie zich rekenschap heeft te geven van het wetenschappelijk wereldbeeld, want dat maakt deel uit van onze levensvorm waarin wij ons bewegen; het is in vereenvoudigde vorm medebepalend voor onze taal, voor onze begrippen of denkvormen, en voor de manier waarop wij ervaren en waarnemen. Hier lijkt voorzichtigheid geboden te zijn: waarneming wordt wel theory-laden genoemd. Daarmee wordt onder andere gezegd dat allerlei aspecten van ons wereldbeeld meespelen in onze manier van kijken en interpreteren van wat wij opmerken. Vertellen onze waarnemingen in het licht van ons huidig wereldbeeld en daarmee verbonden theorieën zoals de werkelijkheid ook 'echt' is? Of zeggen wij dat ons wereldbeeld en onze theorieën de beste middelen zijn die we hebben voor een verklaring van wat wij observeren? Copernicus dacht in zijn tijd de werkelijkheid beter te beschrijven dan de toen gangbare tekening van Ptolemaeus; evenzo dacht Newton dat elk lichaam in het universum een aantrekkingskracht op elk ander lichaam uitoefent en dat zijn theorie tegenover die van Galilei bewegingen het beste beschreef. Einsteins speciale relativiteitstheorie maakte duidelijk dat een begrip als lengte in Newtons mechanica niet meer onafhankelijk is te denken van zwaartekracht, van de beweging van de waarnemer en van de signaalsnelheid, waardoor allerlei tijdruimtelijke begrippen van betekenis veranderen. De kwantumfysica met ondermeer Niels Bohr, Werner Heisenberg, Louis de Broglie en Erwin Schrödinger introduceerde andere voorstellingen voor atomen en deeltjes dan de traditionele beelden. Deeltjes gedragen zich als golven, maar hun plaats en snelheid zijn onmogelijk tegelijk exact te kennen; bovendien geven de golven een maat voor de kans het deeltje op een bepaalde plek aan te treffen in een bepaalde toestand. In 1982 voerde Alain Aspect experimenten uit waarin metingen aan een set gepaarde gepolariseerde fotonen vanuit een gezamenlijke bron steeds het ene foton in een tegenovergestelde lichtrichting lieten zien dan de andere helft van het paar, wat de kwantumtheorie en ook nog iets als actio in distans lijkt te bevestigen. Het interessante van de kwantumfysica blijkt hier dat zij de zaken in relaties tot elkaar en tot hun 'habitat' lijkt te beschrijven. Van welk voorstel kunnen wij nu echter nog zeggen na al deze bijstellingen en veranderingen dat dit nu vertelt zoals de werkelijkheid uiteindelijk 'echt' is? Op dit moment is de kwantummechanica het beste waarover we beschikken, maar kunnen we nu weten of deze nu de finale theorie is? Clayton stelt dat door velen de opvatting gedeeld wordt dat de natuur, op kwantumniveau onbepaald, geen epistemologische maar een ontologische claim inhoudt (Clayton 1997:193-194; Buitendag 2013:1) Ook al denkt men dat de wereld ontologisch niet bepaald ('indeterminate') is op grond van een goedwerkende theorie, men heeft, hoe redelijk deze grond ook is, geen laatste zekerheid. Claytons overtuiging is juist daarom te relativeren.

De bovenstaande voorbeelden laten de ontwikkelingen van theorieën zien waarbij wetenschappers met behulp van beeldtaal (bolletjes, deeltjes en golven) voorstellingen ontwikkelden in de veronderstelling de werkelijkheid te beschrijven zoals deze echt is. Wanneer de beelden problemen opleverden, pasten de fysici de beelden wat aan (zoals golf bezien als waarschijnlijkheidsfunctie). Waarom zouden we onze claims ook niet bijstellen of herinterpreteren? Metaforen vertellen hoe wij met de werkelijkheid zouden kunnen omgaan. Het christelijk geloof acht het woord 'Vader' gepast om God zo aan te spreken zonder te willen beweren dat God daarmee echt afdoende beschreven wordt of model voor alle vaders staat. Wel beweren wij hoe in relatie tot God wij Deze gepast kunnen en mogen tegemoet treden, waarbij de relatie tot God voor het christelijk geloof constitutief is voor zijn perspectief op de werkelijkheid waarin gelovigen zich ingebed zien. Dit heet wel een relationeel realisme: relatie is hier de fundamentele categorie om de netwerken waarin wij leven te beschrijven. Daarbij wordt dus elke vorm van een substantie-ontologie afgewezen. Buitendag bepleit een realisme waarvoor relationaliteit constitutief is, waarbij dit realisme niet de werkelijkheid van God-op-zich poneert, maar de werkelijkheid van het netwerk waarin God met ons verkeert (Buitendag 2013:8). 'Ons soek nie die waarheid nie, ons probeer verstaan', zegt hij voor een zoektocht waarbij natuurwetenschappelijke inzichten theologen sensitief kunnen maken voor theologisch relevante begrippen zoals 'gemeenschap'. Het betekenisveld van 'gemeenschap' verbreedt zich dan tot en met habitat en biotoop (Buitendag 2012:1, 5), waarbij meer omgevingsfactoren een rol spelen dan individueel persoonlijke en sociale karakteristieken, zoals de plaats van mensen te midden van andere lokaal aanwezige levensvormen. 


\section{Erkenning}

De schrijver verklaart hierbij dat hij geen enkele financiële of persoonlijke relatie met enige groepering heeft die hem beïnvloed heeft dit artikel te schrijven zoals hij het heeft geschreven.

\section{Literatuurverwijzingen}

Arnold, J.H., 2000, History: A very short introduction, Oxford University Press, Oxford Kindle edition.

Behr, J., 2013, Irenaeus of Lyons: Identifying Christianity, Oxford University Press, Oxford.

Buitendag, J., 2012, 'Die noodsaaklikheid van habitat in ons definisie van menswees: Op soek na 'n eko-teologiese verstaan van menslike lewe', HTS Teologiese Studies/ Theological Studies 68(1), Art. \#1283, 8 pages. http://dx.doi.org/10.4102/hts. v68i1.1283

Buitendag, J., 2013, 'Gaan na die mier, kyk na sy weë en word wys: Metafoor of paradigma?', HTS Teologiese Studies/Theological Studies 69(1), Art. \#1976, 9 pages. http://dx.doi.org/10.4102/hts.v69i1.1976

Clayton, P.D., 1997, God and contemporary science, Edinburgh University Press, Edinburgh.

Davies, P., 1990, Other worlds, Penguin Books Ltd, London.

Irenaeus, 1995, Adversus Haereses 4, in: Fontes Christiani, Bd. 8/4 , N. Brox (ed.), Herder Verlag, Freiburg.

Irenaeus, 2001, Adversus Haereses 5, in: Fontes Christiani, Bd. 8/5 , N. Brox (ed.), Herder Verlag, Freiburg.
Jenkins, K., 2003, Re-thinking history, Routledge, London.

Moltmann, J., 1980, Trinität und Reich Gottes: zur Gotteslehre, Kaiser Verlag, München.

Moltmann, J., 1985, Gott in der Schöpfung: ökologische Schöpfungslehre, Kaiser Verlag, München.

Moltmann, J., 2002, Wissenschaft und Weisheit: zum Gespräch zwischen Naturwissenschaft und Theologie, Gütersloher Verlagshaus, Gütersloh.

Moltmann, J., 2003, Science and wisdom, transl. M. Kohl, Fortress Press, Minneapolis, $\mathrm{MN}$.

Paul, H., 2014, Als het verleden trekt: Kernthema's in de geschiedfilosofie, Boon Lemma, Amsterdam.

Peacocke, A., 1986, God and the new biology, J.M. Dent \& Sons Ltd, London.

Peacocke, A., 1993, Theology for a scientific age, SCM Press Ltd, London.

Quine, W.V.O., 1981, Theories and things, Harvard University Press, Cambridge, MA.

Scruton, R., 2004, Modern philosophy: An introduction and survey, Pimlico - Random House, London.

Stanford, M., 1998, An introduction to the philosophy of history, Blackwell Publishers Ltd, Oxford.

Van den Brom, L.J., 2011, 'God schept ons een zinvolle ruimte - de metafoor van de eigenzinnige tuinman', in, L.J. van den Brom \& E.R. Jonker (eds.), Zin in leven in de gloria?, pp. 3-23, Protestantse Theologische Universiteit, Utrecht, Kampen, Leiden.

Van den Brom, L.J., 2014, 'Geschiedenis bestaat niet! Theologie van de geschiedenis wel?', Kerk en Theologie 65(4), 335-365.

Walsh, W.H., 1967, An introduction to philosophy of history, Hutchinson \& Co LTD, London.

Zizioulas, J.D., 1997, Being as communion: Studies in personhood and the church, St. Vladimir's Seminary Press, Crestwood, NY. 